\title{
Workspace Satisfaction and Work Behaviour of Computer Systems Managers ${ }^{1}$
}

\section{Ivana Kovačević ${ }^{2}$}

Faculty of Organizational Sciences, University of Belgrade

\section{Svetlana Čizmić}

Faculty of Philosophy, University of Belgrade

\begin{abstract}
Inspired by the equivocal findings of different studies and acknowledging the dynamic nature of relation between situational factors and human behaviour, this research explores the association between satisfaction with psychosocial features of work space and indicators of work behaviour of 116 computer and information systems managers in Serbian companies. Objective differences between openplan and traditional offices were considered, as well as its subjectively experienced characteristics defined by the perception of office capacity to satisfy users ' needs for balance between socializing and individuation at workplace. For that purpose, Workspace Psychosocial Features' Satisfaction Scale was constructed. The items of the scale provoke awareness of the office capacity to satisfy psychosocial needs of users. The principal component factor analysis revealed the congruence of scale composition with expected theoretical content of the concept. It was shown that computer and information systems managers are more satisfied in traditional offices that provide more privacy and personalization. The positive correlation between satisfaction with psychosocial aspects of workspace and self-assessed work behaviour has also been found. Although regression analysis did not show linear association between satisfaction and behaviour on the whole sample, the same analysis for openplan office indicates that there is a possibility to predict someone's work behaviour on the basis of their satisfaction with psychosocial features of their workplace. We tried to explain this finding with the fact that in open-plan offices satisfaction with psychosocial characteristics of space is activated in conditions where employees are directly faced with the need of privacy-interaction regulation with colleagues.
\end{abstract}

Key words: workspace satisfaction, open-plan office, psychosocial needs, work behaviour

1 Članak je rezultat rada na projektima „Primena multimodalne biometrije u menadžmentu identiteta“ (TR32013) i „Identifikacija, merenje i razvoj kognitivnih i emocionalnih kompetencija važnih društvu orijentisanom na evropske integracije“ (179018), čiju realizaciju finansira Ministarstvo prosvete i nauke Republike Srbije.

2 kivana@fon.rs 


\section{Introduction}

\section{Workspace satisfaction and work behaviour}

According to the environment fit theory "satisfaction derives from the perceived congruence between personal preferences or aspirations and the objective and subjective characteristics of place" (Giuliani, 2004, 261). Workspace generates satisfaction when it allows employees to achieve goals and satisfy their needs (Walden, 2004).

Workspace satisfaction has different aspects that are proven to be in relation with the work behaviour and effectiveness (Kamarulzaman, et al. 2011; Oldham, et al. 1991; Sundstrom, 1987), and it is a component of overall job satisfaction (Danielsson \& Bodin, 2008; Gorawara-Bhat, 2000; Knight \& Haslam, 2010; Lee, 2006; Wells, 2000), with which performance is sometimes strongly (Oldham \& Brass, 1979; Oldham \& Fried, 1987; Veitch et al. 2007), and sometimes loosely (Stone \& English, 1998) correlated.

Workplace is a constrained space, organized for accomplishing different business activities, and a polygon where we can observe employees' behaviour, their performance, as well as their activities that are not strictly connected with the working task, the so-called contextual ones (Motowidlo, 2003; Čizmić, 2006).

\section{Office type and satisfaction with workspace}

There is an increasing trend of computer system managers working in open-plan instead of traditional offices, motivated by economic reasons (Maher \& von Hippel, 2005), aesthetics advances (Brookes \& Kaplan, 1972), and by the evidence that this design facilitates and increases interaction between employees with the result of improved satisfaction and productivity (Brennan et al. 2002; Oldham \& Fried, 1987). Nevertheless, their satisfaction with working conditions is rarely considered.

However, there is scientific evidence indicating that occupants experience increased noise, different intrusions and constraints during task performance (Brooks \& Kaplan, 1972; Jahncke et al. 2011; Smith-Jackson \& Klein, 2009), and a provoked feeling of discomfort due to the experience of crowding and high density at the workplace (Danielsson \& Bodin, 2008; Hedge, 1982; Sundstrom, 1987), when working in an open-plan office.

The specific preference is related to the demands of concrete work tasks (their complexity) that are accomplished there (Block \& Stokes, 1989; Douglas et al. 2005; Sutton \& Rafaeli, 1987) and to the specific characteristics of users (Fisher et al. 2004; Maher \& von Hippel, 2005; Mehrabian, 1994). For example, stimulus screening - the ability to neglect irrelevant stimuli (opposite to the arousability trait: Mehrabian, 1977) is proved to be in positive correlation 
with the satisfaction with work environment and with work efficacy (Maher \& von Hippel, 2005) and in negative correlation with tiredness at work and psychosomatic problems (Fried, 2000). Also, self-monitoring ability, as the level in which person's behaviour is based on information obtained from the behaviour of others or from a situation (Snyder, 1974), could be of importance for the established relation between work context and work behaviour.

\section{The workplace psychosocial features and workspace satisfaction}

In different research, there are attempts to consider workspace features through experiencing privacy at the workplace (Haans, et al. 2007; Kupritz, 1997; Maher \& von Hippel, 2005), territoriality as the function of maintaining privacy and control (Brown, 2009), or based on the amount of personal space available for an employee (Douglas et al. 2005), followed by the possibilities of employees to personalize their own workspace (Dinc, 2009; Ferguson et al. 1997). Gorawara-Bhat (2000), for example, sees workplace features as an element of status satisfaction, while Brown (2009) sees a demonstration of one's identity in territorial behaviour in an organization. Moleski and Lang (1982) emphasize the importance of experiencing "freedom of choice" and personal control for satisfaction and performance quality (Bluyssen, et al. 2011; Hurell \& MacLaney, 1989; Lee \& Brand, 2005).

In this study, there is a unique measure of workspace satisfaction based on Altman's theoretical concept of socio-psychological meaning of space (Altman, 1975), consisting of six theoretically relevant indicators of workplace satisfaction: privacy, personal space, territoriality, personalization, identification and status congruency. They all have in common the purpose of regulating communication (dual function of balancing interaction and privacy) and that is the reason why they are seen as psychosocial aspects of workspace.

\section{Research goals and hypotheses}

The aim of this study is to see whether there is a difference in the level of satisfaction with workplace psychosocial characteristics for computer systems managers working in an open-plan and in a traditional office, and to see if there is a correlation between their level of satisfaction, regarding and regardless of office type, and the level of self-evaluated work behaviour.

First, we assessed satisfaction with psychosocial characteristics of workplace in an open-plan office and in traditional office type, applying the scale (Kovačević, 2007) constructed to provoke awareness of spatial capacity to satisfy psychosocial needs of users. 
Second, we established the level of correlation and developed a model of prediction between perception of characteristics of different types of office and work behaviour that includes intervening variables: arousability trait and self-monitoring.

Based on contradictory results of office type preference, some supporting open-plan (Brennan, et al. 2002; Dean et al. 1978) and others inclining towards traditional office types (Danielsson \& Bodin, 2008; Fisher et al. 2004; Oldham \& Fried, 1987; Penn et al. 1999), we postulated that:

Hypothesis 1. There should be differences in satisfaction with the psychosocial characteristics of workspace between those who work as IT managers in open-plan and in traditional types of offices.

There are some indications that there is a correspondence between work satisfaction (when it encompasses workspace) and effectiveness (Crouch \& Nimran, 1989), so there is an assumption that:

Hypothesis 2. There would be a correlation between work behaviour and satisfaction with psychosocial characteristics of work space conceptualized as it is in here.

- Hypothesis 2.1.: respondents whose work behaviour is self-perceived as more excellent, will show more satisfaction with the psychosocial characteristics of work space

- Hypothesis 2.2.: although no specific hypothesis is developed for the effect of intervening variables, we expect that workspace satisfaction will have higher prediction value than self-monitoring and stimulus screening ability.

\section{Method}

Research measures

Physical appearance of work space is a categorical variable varied on two levels: as an open-plan office and as a traditional one.

Satisfaction with workspace psychosocial features is conceptualized as a quantitative variable that represents the level of satisfaction of users' psychosocial needs in a given context. Workplace satisfaction is estimated in its socio-psychological meaning as Altman (1975) has postulated it, on the dimension that describes the relation between the person and his/her social environment: "socio-psychological meaning ... is given by a limited number of bipolar dimensions that characterize the individual's relationship with society, such as identity/communality and accessibility/inaccessibility (or openness/ closeness)" (Giuliani, 2004, 263). 
Work behaviour represents the measure of excellence of workplace behaviour that explains how the person performs work, including not only behaviour directly connected with the work tasks but also connected with work style (Jex \& Britt, 2008). Formal work activities are given in the job and work role descriptions. Contextual activities contribute to the organizational effectiveness through psychological, sociological and organizational context of work. They are based on Coleman and Borman (2000) empirical analysis of the concept that is defined by three factors: interpersonal support, organizational support and individual conscientiousness in performing work tasks.

Self-monitoring is an intervening variable explained as an individual ability to adjust behaviour to the external situational factors. Two components of this concept are found by Lennox and Wolf (1984): ability of modifying self-presentation and susceptibility to expressive behaviour of others.

Second intervening variable is arousability trait, seen as intensity and persistency of person's reaction to stimuli from the environment which is opposite to the stimulus screening ability - ability to neglect irrelevant environmental stimuli (Mehrabian, 1977).

Level of task complexity and task autonomy were kept constant due to the fact that respondents were engaged in the same type of working activities. Personal-demographic variables: gender, age and years of work, were also included in the analysis.

\section{Instruments}

Scale for measuring satisfaction with psychosocial features of workspace measures level in which workplace characteristics satisfy social and psychological needs of their occupants. Scale was developed by the authors of the present study for the purposes of this research and it was verified in a preliminary study (Kovačević, 2007), where internal consistency of 36 items was reasonably high (Crombach `s alpha $=.91)^{3}$. This scale is based on the assumption that indicators are psychosocial needs present in a certain amount in every person and that the degree of agreement with the statements will represent a measure of satisfaction that the workplace provides for users' needs, and, consequently, overall satisfaction.

Work behaviour self-assessment scale quantifies the level of excellence of performed tasks. It considers behaviour directly connected with formal work demands, as well as psychosocial and organizational aspects of performing work. The scale is based on Borman and Motowidlo`s (1993)

3 Scale indicators and items are provided in the appendix. 
concept of work behaviour, and Coleman and Borman (2000) empirical verification. This scale has an internal consistency of alpha $=.79$, for 27 items. It appraises the quality and quantity of performance: the amount and excellence of work done according to one's estimation, level of persistence, taking initiative, enthusiasm, accuracy, reliability while working on tasks (work style), amount of cooperation, courtesy, emotional support, timely informing, trustworthiness, adaptability and organizational loyalty, commitment and rule conformity (similar to the concept of organizational citizenship behaviour).

Standard questionnaire was administered to obtain data for respondents' personal-demographic characteristics.

Self-monitoring is measured by the translated Lennox and Wolf's (1984) version of Self-monitoring scale. This revisited version has a higher internal consistency $(\mathrm{alpfa}=.86)$ from the original Snyder's scale from 1974. Thirteen items of this scale encompass two factors: the ability to shape self-presentation based on social information from the environment and responsiveness to expressive behaviour of others. In our research internal consistency of the scale was found to be of alpha $=.88$.

The latest version of Mehrabian's Trait Arousability Scale (TAS) ${ }^{4}$ is used for estimation of the stimulus screening ability. This scale has 34 items demanding from respondents to assess the level of their agreement on a nine-grade scale. Although it might seems heterogeneous, this scale has a reasonably high internal consistency of K-R coef. $=.90$ (Mehrabian, 1994), which is verified in our research, with the alpha $=.87$.

\section{Sample}

Sample consisted of 116 engineers employed in IT sector of several companies (15) located on the territory of Belgrade, working on different types of software problems with a similar degree of complexity. After the work analysis procedure conducted in preliminary research, we understood that their work consisted of intellectually demanding tasks with constant utilization of information-communication technology (Kovačević, 2007).

From 116 valid cases, 50.86\% were working in open-plan offices and $49.14 \%$ in the traditional ones. This was partially because there were more companies that favoured an open-plan office for this particular kind of work.

Respondents in our sample were performing tasks with a similar degree of complexity and autonomy. $65.5 \%$ of them were male, over $50 \%$ were younger

4 We obtained a written permission for application of this scale from the author Albert Mehrabian in 2007, with the prohibition of non-authorized copying and publishing. 
than 30 , with 1 to 5 years of working in the company. The response rate was relatively high, it was more than $80 \%$ (116 responded from 139 contacted). Also, in several companies (three), response rate was indisputably higher and those were the companies where we built fine rapport with the supervisor. This relation could have had some vague impact on our results, due to the fact that we included factors of socio-psychological satisfaction in our research (and they might depend on interpersonal relations and trust in supervisor), but because of the small number of cases in each company we omitted analysis of its potential impact.

\section{Data collecting and data processing (statistical analysis)}

Data were collected in April 2007, from fifteen Serbian companies, where seven of them were software developing companies, six were banks, and two of them mobile telephone providers. Nevertheless, respondents were working in the informatics sector as technical support. Although it might seem that the selection of companies was random, the reason why we chose these companies is that they employed computer systems managers. We obtained an approval from their supervisor for filling the questionnaires. Respondents filled out four paper-based tests (110 items in total), and answered questions considering demographic data.

Although we insisted on anonymity of data and scientific purposes of research (which was emphasized in the motivation letter and introduction into scales), some of our respondents were not willing to answer, mainly because of the fact that demographic data were included. We found an interesting but not scientifically verified pattern of behaviour of our respondents. It was obvious that if they had respectable confidence in their supervisors they were willing to participate; if not, they decided to withdraw from further participation.

\section{Results}

Workspace satisfaction and work behaviour in the context of office type and personal characteristics of their users

Significant differences in workplace satisfaction between employees working in an open-plan and in a traditional office were found. Those working in traditional offices show more satisfaction with the psychosocial features of workspace than those working in open- plan offices $(t=.3 .84$; $\mathrm{p}<.001$ ). 
Table 1: Descriptive statistics of samples' workspace satisfaction and work behaviour including intervening variables

\begin{tabular}{|c|c|c|c|c|c|c|}
\hline Scales & Office type & $A S$ & $S D$ & Min. & Max. & $\mathrm{N}$ \\
\hline \multirow{4}{*}{ Workspace satisfaction } & traditional & 127,32 & 19,71 & 76 & 158 & 57 \\
\cline { 2 - 7 } & open-plan & 112,29 & 22,34 & 73 & 154 & 59 \\
\cline { 2 - 7 } & sum & 119,67 & 22,31 & 73 & 158 & 116 \\
\hline \multirow{4}{*}{ Self-monitoring } & traditional & 46,67 & 8,02 & 24 & 60 & 57 \\
\cline { 2 - 7 } & open-plan & 45,17 & 9,79 & 21 & 63 & 59 \\
\cline { 2 - 7 } & sum & 45,91 & 8,96 & 21 & 63 & 116 \\
\hline \multirow{3}{*}{ Arousability trait } & traditional & 107,19 & 20,84 & 60 & 154 & 57 \\
\cline { 2 - 7 } & open-plan & 108,54 & 21,21 & 55 & 162 & 59 \\
\cline { 2 - 7 } & sum & 107,88 & 20,95 & 55 & 162 & 116 \\
\hline Work behaviour & traditional & 97,86 & 12,87 & 47 & 117 & 57 \\
\cline { 2 - 7 } & open-plan & 99,42 & 9,80 & 82 & 125 & 59 \\
\cline { 2 - 7 } & sum & 98,66 & 11,39 & 47 & 125 & 116 \\
\hline
\end{tabular}

Table 2: Correlation between scales for traditional and open-plan offices

\begin{tabular}{|c|c|c|c|c|}
\hline Office type & Scales & Self-monitoring & $\begin{array}{c}\text { Arousability } \\
\text { trait }\end{array}$ & $\begin{array}{c}\text { Work } \\
\text { behaviour }\end{array}$ \\
\hline \multirow{3}{*}{$\begin{array}{l}\text { Traditional } \\
\qquad \mathrm{N}=57\end{array}$} & $\begin{array}{l}\text { Workspace } \\
\text { satisfaction }\end{array}$ & $0,27^{\star}$ & 0,03 & 0,07 \\
\hline & Self-monitoring & & 0,18 & 0,15 \\
\hline & Arousability trait & & & 0,19 \\
\hline \multirow{3}{*}{$\begin{array}{l}\text { Open-plan } \\
\mathrm{N}=59\end{array}$} & $\begin{array}{l}\text { Workspace } \\
\text { satisfaction }\end{array}$ & $0,47^{\star *}$ & 0,00 & $0,49^{\star *}$ \\
\hline & Self-monitoring & & 0,15 & $0,36^{*}$ \\
\hline & Arousability trait & & & 0,23 \\
\hline
\end{tabular}

${ }^{\star}$ level of significance $\mathrm{p}<.005$

** level of significance $\mathrm{p}<.001$

As shown in Table 2, workplace satisfaction obtained from workers in an open-plan office environment is in a positive and relatively strong correlation with work behaviour. Satisfaction with workspace features is also positively correlated with the self-monitoring ability both in open-plan and traditional offices. Employees, especially those working in open-plan offices, with higher ability to monitor self-behaviour, are also more satisfied with psychosocial aspects at their workplace. Shaping self-presentation and understanding expressive behaviour of others lead people to be more satisfied with psychosocial opportunities that the workplace offers. It has been shown that stimulus screening ability (trait arousability) has no effect on the relation between workplace satisfaction and work behaviour. 
Workspace satisfaction as a predictor of work behaviour

Regression analysis shows that neither of variables could predict work behaviour for the whole sample, but there are different patterns of predictors' influence when we take into account sub-samples based on office types.

Regression model for a traditional office is not statistically significant, and hence it is not reliable to predict work behaviour based on variables included in this model.

On the other hand, the regression model for an open-plan office (WB=61.899 $+0.0986 \mathrm{TA}+0.132 \mathrm{SM}+0.186 \mathrm{WSFS}$ ) is found to be statistically significant $(\mathrm{F}=7.96 ; \mathrm{p}<.01)$, with the component of workspace features' satisfaction statistically significant and the most influential in the model of prediction.

Graph 1a: Scaterrplots of regression models with confidence interval for a traditional office

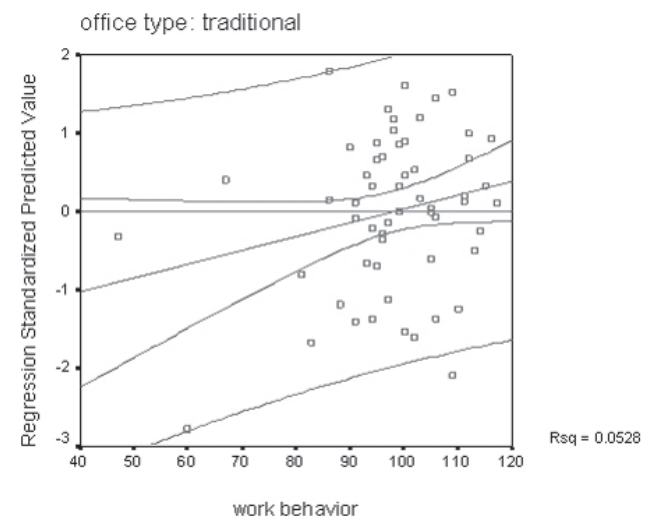

Graphs 1b: Scaterrplots of regression models with confidence interval for an open-plan office

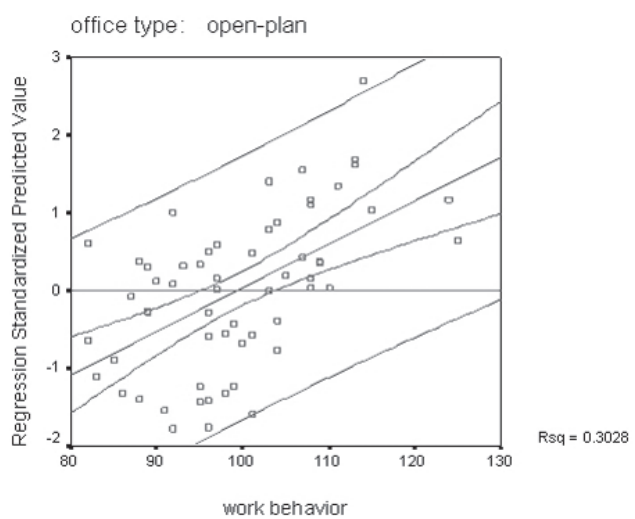


According to the model, work behaviour of employees working in openplan offices could be predicted in about $30 \%$ of cases ( $r$ square $=.303 ; \mathrm{p}<.01$ ). Therefore, employees who are more satisfied with open-plan office would also have higher scores on work behaviour indexes.

\section{Discussion and conclusion}

Based on contradictory findings of different surveys of users' preferences for open-plan or traditional offices (Brennan et al. 2002; Fisher et al. 2004), the first hypothesis was postulated. Statistically significant differences were found regarding the satisfaction with psychosocial characteristics of workspace for open-plan and traditional offices, confirming the first hypothesis. It was shown that IT managers in our sample were more satisfied with working in space of traditional offices that provide more privacy and more opportunities for personalization than working in popular open-plan offices. It is in concordance with the results of some previous research (Brooks \& Kaplan, 1972; Hedge, 1982; Sundstrom, 1987).

Practically, working in an open-plan office, according to the mental capacity model (Oborne, 1987), for IT managers means functioning at the level of work demands that is out of the optimum range. Some findings corroborate this in the context of unwanted intrusions when there is a lack of mental engagement in task performance (Oldham et al. 1991), and others are controversial, claiming that noise impairs performance on cognitive tasks (Jahncke et al. 2011; Block \& Stokes, 1989), with especially high mental workload in the presence of irrelevant speech noise (Smith-Jackson \& Klein, 2009).

Although positive correlation between satisfaction with psychosocial aspects of the workspace and work behaviour is relatively weak and present on the lower level of significance, it directs us toward the conclusion that the second hypothesis was confirmed with limitations in its interpretation. Further, regression analysis did not show linear association between satisfaction and behaviour on the whole sample but the same analysis for open-plan office proved that there was a possibility to predict someone's work behaviour on the basis of their satisfaction with psychosocial features of their workplace. This result is in concordance with that of Veitch and associates (Veitch et al. 2007), where employees working in an open-plan office, who were more satisfied with it, were also more satisfied with their jobs, indicating higher organizational effectiveness.

A possible explanation is the fact that inevitable everyday interaction with colleagues in an open-plan office provokes different mechanisms of adjusting to other occupants and regulating interaction, consequently generating individual satisfaction and effectiveness in social context and opportunities 
for self-preservation. It is consistent with the concept of situational awareness, when one becomes conscious of the environment as the result of the requirement to adapt to some of its aspects (Ittelson et al. 1974).

Further, if there is an opportunity to control situational conditions, the sense of accomplishment and independence is higher (Trancik \& Evans, 1995), as well as performance outcomes (O'Neill, 2010), while awareness itself is considered to be a first step in taking a proactive attitude towards environmental control (Horhe Martin, 2002; Mehrabian, 1977). In an openplan office context, increased satisfaction due to the increased environmental control (Bluyssen, at al. 2011; Danielsson \& Bodin, 2008), amongst all, provoke experience of higher work behaviour excellence (Lee \& Brand, 2005), where in traditional offices other factors have to be traced.

Although results of this study confirm both hypotheses to the same extent, it is not wise to bring up the same definite conclusion about the suitable type of office for IT managers. Due to the restriction of this sample, results could be extrapolated on the population of IT managers working in Serbian companies. Nevertheless, there should be a recommendation to be cautious with the open-plan office arrangement. Obviously, in the context of an open-plan office, which elicits less overall satisfaction, psychosocial features become relevant for the work behaviour appraisal, where other factors should be considered in traditional offices.

As employees' personal characteristics treated here were not overly significant, some other factors should be taken into consideration in further research. For example, space personalization is found to be of importance for developing self-esteem (Maxwell \& Chmielewski, 2008). Also, there are some indications that spatial psychosocial needs are dependent on individual differences in personality traits (Wells \& Thelen, 2002) and in gender (Dinc, 2009; Yildirim, et al. 2007).

The fact that the response rate was higher in the companies where there was a higher trust in supervisor might be an indication that we should include this particular relation into the research problem. Therefore, managerial attitude towards personalization and autonomy that provoke higher organizational identification (Knight \& Haslam, 2010) or positively evaluated ambient conditions as a moderating variable between supervisor's support and organizational commitment (Rousseau \& Aube, 2010, Wells et al. 2007) could be considered.

In this study, we neglected the aspect of overall organizational culture that permits some degree of employees' personal control and personalization. As Wells (Wells \& Thelen, 2002) found that personalization is mainly predicted by the organizational policy, and that organizational culture has an indirect effect on personalization (Wells et al. 2007), this concept should be included in further research. 


\section{References}

Altman, I. (1975). The environment and social behavior. Monterey, CA: Brooks/Cole.

Borman, W. C., \& Motowidlo, S. J. (1993). Expanding the criterion domain to include elements of contextual performance. In N. Schmitt, \& W. C. Borman (Eds.). Personnel Selection in Organizations (pp. 71-98). San Francisco, CA: Jossey Bass.

Block, K. L., \& Stokes, G. S. (1989). Performance and satisfaction in private versus nonprivate work settings. Environment and Behavior, 21(3), 277-297.

Bluyssen, P. M., Aries, M., \& van Dommelen, P. (2011). Comfort of workers in office buildings: The European HOPE project. Building and Environment, 46, 280-288.

Brennan, A., Chugh, J. S., \& Kline, T. (2002). Traditional versus open office design. Environment and Behavior, 34(3), 279-299.

Brookes, M. J., \& Kaplan A. (1972). The office environment: Space planning and affective behaviour. Human Factors, 14, 373-391.

Brown, G. (2009). Claming a corner at work: Measuring employee territoriality in their workspaces. Journal of Environmental Psychology, 29, 44-52.

Coleman, V. I., \& Borman, W. C. (2000). Investigating the underlying structure of the citizenship performance domain. Human Resource Management Review, 10, 25-44.

Crouch, A., \& Nimran, U. (1989). Office design and the behavior of senior managers. Human Relations, 42(2), 139-155.

Čizmić, S. (2006). Ljudski faktor. Osnovi inženjerske psihologije. Beograd: Filozofski fakultet, Institut za psihologiju.

Danielsson, C. B., \& Bodin, L. (2008). Office type in relation to health, well-being, and job satisfaction among employees. Environment and Behavior, 40(5), 636-668.

Dean, L., Pugh, W., \& Gunderson, E. (1978). The Behavioral Effects of Crowding. Environment and Behavior, 10, 419-431.

Dinc, P. (2009). Gender (in)difference in private offices: A holistic approach for assessing satisfaction and personalization. Journal of Environmental Psychology, 29, 53-62.

Douglas, M., Oldham, G. R., \& Rathert, C. (2005). Employee affective and behavioral reactions to the spatial density of physical work environments. Human Resource Management, 44(1), 21-33.

Ferguson, D. S., Horan, H., \& Ferguson, M. A. (1997). Indicators of permanence in workspace features: Perceived importance and relationship to workspace satisfaction. Canadian Journal of Communication, 22, 61-80.

Fisher, G. N., Tarquinio, C., \& Vischer, J. C. (2004). Effects of the self-schema on perception of space at work. Journal of Environmental Psychology, 24, 131-140.

Fried, M. (2000). Continuities and discontinuities of place. Journal of Environmental Psychology, 20, 193-205.

Gorawara-Bhat, R. (2000). The Social and Spatial Ecology of Work: The Case of a Survey Research Organization, New York: Kluwer Academic.

Giuliani, V. M. (2004). Residential preferences and attachment across the lifespan. In C. Spielberger (Ed.), Encyclopedia of applied psychology (pp. 267-272). eBook: Elsevier Academic Press.

Haans, A., Kaiser, F. G., \& de Kort, Y. A. W. (2007). Privacy needs in office environments. European Psychologist, 12(2), 93-102. 
Hedge, A. (1982). The open-plan office. A systematic investigation of employee reactions to the work environment. Environment and Behaviour, 14, 519-542.

Horhe Martin, S. (2002). The classroom environment and its effects on the practice of teachers, Journal of Environmental Psychology, 22, 139-156.

Ittelson, W. H., Proshansky, H. M., Rivlin, L. G., \& Winkel, G. H. (1974). An introduction to environmental psychology, New York: Holt, Riverhart \& Winston inc.

Jahncke, H., Hygge, S., Halin, N., Green, A., \& Dimberg, K. (2011). Open-plan office noise: Cognitive performance and restoration. Journal of Environmental Psychology, 31, 373-382.

Jex, S. M. (2008). Productive behavior in organizations. In S. M., Jex, \& T. W., Britt (eds.). Organizational psychology: A scientist-practitioner approach (pp.87-109). New York: John Wiley \& Sons.

Kamarulzaman, N., Saleh, A. A., Hashim, S. Z., Hashim, H., \& Abdul-Ghani, A. A. (2011). An overview of the influence of physical office environments towards employees. Procedia Engineering, 20, 262-268.

Knight, C., \& Haslam, A.S. (2010). Your place or mine? Organizational identification and comfort as mediators of relationships between the managerial control of workspace and employees' satisfaction and well-being. British Journal of Management, 21, 717-735.

Kovačević, I. (2007). Zadovoljstvo psihosocijalnim karakteristikama radnog prostora $i$ radno ponašanje (Magistarski rad, Filozofski fakultet, Univerzitet u Beogradu).

Kupritz, V.W. (1998). Privacy in the work place: The impact of building design. Journal of Environmental Psychology, 18, 341-356.

Lee, S.Y. (2006). Expectations of employees toward the workplace and environmental satisfaction. Facilities, vol. 24(9/10), 343-353.

Lee, S. Y., \& Brand, J. L. (2005). Effects of control over office workspace on perceptions of the work environment and work outcomes. Journal of Environmental Psychology, 25, 323-333.

Lennox, R. D., \& Wolfe, R. N. (1984). Revision of the Self-Monitoring Scale. Journal of Personality and Social Psychology, 46(6), 1349-1364.

Maher, A., \& von Hippel, C. (2005). Individual differences in employee reactions to open-plan offices. Journal of Environmental Psychology, 25, 219-229.

Maxwell, L. E., \& Chmielewski, E. J. (2008). Environmental personalization and elementary school children's self-esteem. Journal of Environmental Psychology, 28, 143-153.

Mehrabian, A. (1977). Individual differences in stimulus screening and arousability. Journal of Personality, 45, 237-250.

Mehrabian, A. (1994). Manual for the revised Trait Arousability (converse of the Stimulus Screening) Scale. Available from Albert Mehrabian,1130 Alta Mesa Road, Monterey, CA, USA 93940.

Moleski, W. H., \& Lang, J. T. (1982). Organizational needs and human values in office planning. Environment and Behavior, 14(3), 319-332.

Oborne, J. D. (1987). Ergonomics at work, Chichester: JohnWiley \& Sons.

Oldham, G. R., \& Brass, D. J. (1979). Employee reactions to an open plan office: A naturally occurring quasi-experiment. Administrative Science Quarterly, 24, 267-284. 
Oldham, G. R., \& Fried, Y. (1987). Employee reactions to workspace characteristics. Journal of Applied Psychology, 72(1), 75-80.

Oldham,.G. R, Kulik, C. T., \& Stepina, L. P. (1991). Physical environments and employee reactions: Effects of stimulus screening skills and job complexity. Academy of Management Journal, 34(4), 929-938.

O 'Neill, M. J. (2010). A model of environmental control and effective work. Facilities, 28(3/4), 118-136.

Penn, A., Desyllas, J. \& Vaughan, L., (1999). The space of innovation: interaction and communication in the work environment. Environmental and Planning B: Planning and Design, 26, 193-218.

Rousseau, V., \& Aube, C. (2010). Social support at work and affective commitment to the organization: The moderating effect of job resource adequacy and ambient conditions. The Journal of Social Psychology, 150(4), 321-340.

Smith-Jackson, T. L., \& Klein, K.W. (2009). Open-plan offices: Task performance and mental workload. Journal of Environmental Psychology, 29, 279-289.

Snyder, M. (1974). Self-monitoring of expressive behavior, Journal of Personality and Social Psychology, 30, 526-537.

Stone, N.,J., \& English, A. J. (1998). Task type, posters and workspace color on mood, satisfaction, and performance. Journal of Environmental Psychology, 18, 175-185.

Sundstrom, E. (1987). Work Environments: Offices and factories. In D. Stokols \& I. Altman (eds.). Handbook of environmental psychology, (733-782). New York: Wiley-Interscience.

Sutton, R. I., \& Rafaeli, A. (1987). Characteristics of workstations as potential occupational stressors. Academy of Management Journal, 30, 260-276.

Trancik, A.M., \& Evans, G.W. (1995). Spaces fit for children: competency in the design of daycare center environments, Children's Environments, 12, 311-319.

Veitch, J. A., Charles, K. E., Farley, K. M. J., \& Newsham, G. R. (2007). A model of satisfaction with open-plan office conditions: COPE field findings. Journal of Environmental Psychology, 27, 177-189.

Walden, R. (2004). Work Environments. In C. Spielberger (Eds.) Encyclopedia of Applied Psychology (pp. 15-18). eBook: Elsevier Academic Press.

Wells, M. M. (2000). Office clutter or meaningful personal displays: the role of office personalization in employee and organizational well-being. Journal of Environmental Psychology, 20, 239-255.

Wells, M.M., \& Thelen, L. (2002). What does your workspace say about you? The influence of personality, status and workspace on personalization. Environment and Behavior, 34(3), 300-321.

Wells, M. M., Thelen, L., \& Ruark, J. (2007). Workspace personalization and organizational culture: Does your workplace reflect you or your company? Environment and Behavior, 39(5), 616-634.

Yildirim, K., Akalin-Baskaya, A., \& Celebi, M. (2007). The effects of window proximity, partition height, and gender on perceptions of open-plan offices. Journal of Environmental Psychology, 27, 154-165. 


\section{Appendix No.1:}

\section{Scale of satisfaction with workspace psychological features}

Personal space indicators:

1. The amount of available space at my working place allows me to perform and complete all my working tasks successfully

2. Interference with each other's activities is a common phenomenon at my workplace

3. At my workplace, I do not have enough space for myself

4. I feel that my working colleagues are too much in close proximity from me

5. My colleagues often jeopardize my personal space

Territoriality indicators:

6. My working place is adequately separated from the working surfaces of my colleagues

7. My workplace cannot be used by others unless they ask for my permission (without my permission)

8. At my work place, only me and me alone, can leave things

9. Even when I am not at work, my workplace is exclusively mine

10. I feel safe at my workplace

Personalization indicators:

11.I use my workplace to leave a lot of personal stuff

12. It is allowed for me at my workplace to post personal photos and whatever photos I like

13. It is allowed for me to decorate my workplace how I like

14. I can organize my workplace according to my own needs

15. My workplace is full of my personal belongings

Identification indicators:

16. At my workplace I feel "at home"

17.I believe that the appearance of my workplace describes, expresses me as a person, too

18. The appearance of my workplace is in accordance with my life style

19. I see the workplace that I am using as a reflection of my professionalism

20. My work behaviour is often dictated by the appearance of my workspace 
Status congruency indicators:

21. The characteristics of my workspace are entirely appropriate to my organizational status

22. Workspace that I am assigned is in concordance with my expectations, considering my organizational status

23. Amount of space disposable for me at my workplace is similar to the amount of space available for other colleagues of same organizational status

24. Compared with workspaces of colleagues with same organizational status, my workplace looks disagreeable

25. I reckon that an employee with my organizational status deserves a better workplace

Privacy/interaction regulation indicators:

26. My workplace enables me to reveal to my colleges as much information as it suits me

27.I often feel isolated at my workplace

28. At my workplace I often feel exposed to the glances of my colleagues

29. Colleagues at my workplace can hear all my conversations most of the time

30. My workplace is positioned in such a way that I am available (disposable, on disposal) to my colleagues all the time

31. My workplace offers me an opportunity to be in constant contact with my colleagues

32. Sitting at my workplace I usually can hear what my colleagues are talking about

33. Due to the position of my workplace, all information that is available to my colleagues is also accessible to me

34. My workplace facilitates closeness between me and my colleagues

35. At my workplace, it is not possible for me to relax and to be free of interruptions (intrusions)

36. Conditions at my workplace are such that it is impossible not to know everything about everyone 


\title{
Zadovoljstvo radnim prostorom i radno ponašanje menadžera informacionih tehnologija
}

\section{Ivana Kovačević}

Fakultet organizacionih nauka, Univerzitet u Beogradu

\author{
Svetlana Čizmić \\ Filozofski fakultet, Univerzitet u Beogradu
}

Inspirisano oprečnim rezultatima ranijih istraživanja i analizom dinamike odnosa sredinskih činilaca i ponašanja zaposlenih, ovo istraživanje ima za cilj ispitivanje veze između zadovoljstva psihosocijalnim karakteristikama radnog prostora, s jedne strane, i radnog ponašanja 116 menadžera kompjuterskih i informacionih sistema, s druge. U istraživanju su uzete u obzir kako objektivne razlike između kancelarija otvorenog tipa i tradicionalnih kancelarija namenjenih za jednog korisnika, tako i subjektivni doživljaj tih karakteristika, svedenih na procenu stepena u kojem taj prostor zadovoljava potrebe korisnika sa aspekta ravnoteže između mogućnosti za interakciju i čuvanja privatnosti koje on pruža.U cilju procene subjektivnog zadovoljstva stepenom u kojem različiti tipovi kancelarije omogućavaju optimalan nivo interakcije i privatnosti, konstruisana je Skala zadovoljstva psihosocijalnim karakteristikama radnog prostora. Dobijena je visoka interna konzistentost skale, a analiza glavnih komponenti pokazala je visoko slaganje između pokazatelja i teorijski definisanog sadržaja koncepta. Rezultati su nedvosmisleno pokazali da su menadžeri informacionih i kompjuterskih sistema zadovoljniji u tradicionalnom tipu kancelarije koji obezbeđuje veću kontrolu privatnosti i interakcije. Nađena je i pozitivna korelacija između zadovoljstva psihosocijalnim karakteristikama radnog prostora i samoprocenjenog radnog ponašanja. Iako regresiona analiza nije pokazala postojanje linearne povezanosti između zadovoljstva i radnog ponašanja na celom uzorku, ona je dobijena na uzorku ispitanika koji rade u kancelarijama otvorenog tipa. To nam omogućava da sa izvesnim stepenom verovatnoće predvidimo nečije radno ponašanje na osnovu njegovog zadovoljstva psihosocijalnim karakteristikama radnog prostora sa kancelarijama otvorenog tipa. Ovaj nalaz je objašnjen činjenicom da u kancelarijama otvorenog tipa zadovoljstvo psihosocijalnim karakteristikama prostora biva aktivirano jer su u ovim uslovima zaposleni direktno suočeni s potrebom regulacije privatnosti i interakcije sa drugima.

Ključne reči: zadovoljstvo radnim prostorom, kancelarija otvorenog tipa, psihosocijalne potrebe, radno ponašanje. 